\title{
Analisis Dampak Platform Peer-To-Peer Airbnb Terhadap Usaha Perhotelan Konvensional di Provinsi Bali
}

\author{
I Dewa Gede Ganapati *1, Tatan Sukwika², Yohanes Sulistyadi ${ }^{3}$ \\ Program Studi Magister Manajemen, Sekolah Pascasarjana \\ Universitas Sahid Jakarta, $10220^{123}$ \\ Email: dewa.ganapati@gmail.com
}

\begin{abstract}
The sharing economy platforms in the accommodation, such as Airbnb, gain more public attention. Several hoteliers in Indonesia have complained about the unequal playing of the field due to the alleged tax violations. Some studies on the impact of Airbnb have been discussed in various countries, but this subject has not been widely conducted in Indonesia. This study aims to determine the impact of Airbnb on the conventional hotel industry in Bali and how the conventional hotel's response to compete with Airbnb. This research was conducted using qualitative research. Data was collected through interviews and secondary data collection. Interviews were conducted with representatives of hoteliers, Airbnb owners, and hospitality associations in Bali. Using forecasting analysis, this study finds that the presence of Airbnb in Bali has an impact on the occupancy rate of conventional hotels in Bali. However, there doesn't a significant impact from Airbnb regarding the hospitality revenue. Meanwhile, conventional hoteliers generally do not make particular efforts to compete with Airbnb. This research implies for the managerial side of hotels and public programs and policies, especially for the Government of Bali in the future to pay attention to consumer protection to provide equal action between conventional hotel and Airbnb owners.
\end{abstract}

Keywords: Impact of Airbnb; Sharing Economy; Hotels

\begin{abstract}
Abstrak
Airbnb sebagai platform sharing economy pada bisnis akomodasi terus mendapatkan perhatian masyarakat. Sejumlah pelaku usaha perhotelan di Indonesia mengeluhkan tidak setaranya playing of field dengan Airbnb terutama dugaan pelanggaran terhadap pajak. Meski sejumlah penelitian mengenai dampak Airbnb telah dibahas di berbagai negara, penelitian mengenai hal tersebut belum banyak dilakukan di Indonesia. Penelitian ini bertujuan mengetahui dampak Airbnb terhadap industri perhotelan konvensional di Provinsi Bali serta mengetahui bagaimana respon pelaku industri perhotelan konvensional bersaing dengan Airbnb. Penelitian ini dilakukan dengan penelitian kualitatif. Pengumpulan data dilakukan melalui wawancara dan pengambilan data sekunder. Wawancara dilakukan dengan perwakilan pelaku usaha perhotelan, pemilik Airbnb, dan asosiasi perhotelan di Bali. Menggunakan analisis peramalan dengan pemodelan, penelitian ini menemukan bahwa keberadaan Airbnb di Bali telah berdampak bagi tingkat penghunian hotel konvensional di Bali. Namun, dari sisi pendapatan perhotelan tidak nampak adanya dampak yang signifikan dari adanya Airbnb. Sementara itu, pelaku usaha perhotelan konvensional tidak melakukan upaya khusus untuk bersaing dengan Airbnb. Penelitian ini berimplikasi pada sisi manajerial hotel serta pada program dan kebijakan publik terutama bagi Pemerintah Bali untuk kedepannya lebih memberikan perhatian dalam perlindungan konsumen hingga memberikan kesamaan perlakuan antara pelaku usaha hotel konvensional dengan pemilik Airbnb.
\end{abstract}

Kata Kunci: Dampak Airbnb; Sharing Economy; Perhotelan

\section{A. PENDAHULUAN}

Sejak tahun 2013 lalu, sejumlah platform penyediaan akomodasi bermunculan dan berkembang di Indonesia. Berbagai platform tersebut adalah Airbnb, VRBO, HomeAway, dan FlipKey. Hanya saja, Airbnb lebih banyak digunakan oleh penyedia akomodasi dan memiliki jumlah pengguna yang banyak di Indonesia. Platform tersebut tidak memerlukan waktu yang lama untuk mengambil hati konsumen, 
dengan kemudahan yang diberikan serta tawaran peningkatan efisiensi kepada konsumen menjadi daya darik tersendiri.

Airbnb menawarkan bisnis model berupa peer-to-peer economy, atau juga dikenal dengan sharing economy, yang memberikan pengalaman yang berbeda bagi konsumen untuk mendapatkan akomodasi. Dalam hal ini, jenis usaha yang dijalankan oleh Airbnb pada dasarnya merupakan usaha tradisional, hanya saja Airbnb memberikan added value dengan menggunakan teknologi informasi yang berkembang.

Airbnb sudah dikenal dan telah digunakan olah sejumlah traveler yang berkunjung ke Indonesia. Pada tahun 2017 lalu, tercatat sebanyak 43.700 penyedia unit Airbnb yang terdaftar dan telah digunakan oleh lebih dari 880.000 orang, dengan pemasukan bagi tuan rumah di Indonesia pada umumnya memperoleh Rp 28,4 juta atau US\$2.100 (CNN, 2017). Pada tahun 2016 total pendapatan yang diterima tuan rumah di Indonesia mencapai Rp 1,15 triliun atau US\$ 84,6 juta. Hingga saat ini, Airbnb merupakan market leader dalam penyediaan akomodasi berbasis sharing economy.

Meski membawa sejumlah kemudahan bagi konsumen, kehadiran platform peer-to-peer economy seperti Airbnb secara empiris juga membawa dampak negatif bagi daerah. Bagi pelaku usaha perhotelan konvensional, Airbnb berdampak pada performansi hotel (seperti tingkat penghunian kamar dan pendapatan) hingga kenaikan harga lahan yang dapat berujung gentrifikasi (Benítez-Aurioles, 2019; Chattopadhyay \& Mitra, 2020; Dogru, Hanks, Mody, et al., 2020; Ginindza \& Tichaawa, 2019). Meski demikian, tidak berarti bahwa Airbnb memiliki dampak yang sama pada setiap lokasi/daerah (Dogru, Hanks, Ozdemir, et al., 2020).

Berbagai penelitian terdahulu telah mencoba untuk menggali dampak Airbnb kepada hotel konvensional melalui sejumlah metode analisis yang beragam. Sejumlah metode yang digunakan antara lain regresi, pemodelan dengan pendekatan ekonometri, hingga menggunakan unstructured covariance model. Dampak Airbnb terhadap hotel konvensional secara umum diukur dengan indikator pendapatan hotel (RevPAR) (Blal et al., 2018; Dogru et al., 2019; Xie \& Kwok, 2017). Meski demikian, Ginindza dan Tichaawa (2019) juga melihat dampak Airbnb berdasarkan occupancy rate. Berbagai penelitian terdahulu menyimpulkan bahwa dampak Airbnb terhadap hotel konvensional tidak dapat digeneralisir. Misalnya, apabila harga jual kamar hotel lebih rendah daripada Airbnb di sekitarnya, hotel tersebut tetap akan mendapatkan keuntungan. Selain itu, misalnya di Swaziland ditemukan bahwa Airbnb tidak berdampak secara signifikan terhadap occupancy rate.

Berbagai penulis berpendapat bahwa Airbnb dapat berfungsi sebagai substitusi bagi hotel tertentu, sehingga berdampak pada pendapatan hotel, dan bahwa dampak tersebut dapat dibedakan: berdasarkan wilayah geografis, menurut segmen pasar hotel, dan berdasarkan musim. Pengusaha hotel konvensional baru-baru ini mulai mengambil pilihan untuk berkompetisi dengan Airbnb dan menganggapnya sebagai ancaman serius. Sebagai contoh, asosiasi hotel telah mengeluarkan secara terbuka pernyataan penolakan terkait pesaing seperti Airbnb, dengan alasan bahwa mereka menargetkan segmen pasar yang sama dengan yang ditargetkan oleh rantai hotel konvensional.

Namun demikian, menurut Airbnb, di banyak kota lebih dari 70\% properti Airbnb berada di luar kawasan perhotelan, yang justru berarti menunjukkan hubungan yang saling melengkapi/komplementer. Meskipun Airbnb dipandang memiliki sejumlah advantage dibanding usaha hotel konvensional, ada faktor-faktor yang tetap 'menguntungkan' hotel yaitu menyangkut alasan keamanan, kebersihan, dan kualitas yang sangat terjamin, dan bahkan 34\% konsumen yang biasa menggunakan Airbnb, mereka masih mempercayai merek hotel terkemuka daripada Airbnb untuk acara-acara tertentu (Lieberman, 2015).

Meski saat ini Airbnb telah berkembang pesat dalam beberapa tahun terakhir, namun platform tersebut menghadapi rintangan dari sejumlah pemilik tanah dan pelaku industri 
perhotelan. Sejumlah pihak tersebut mengkritik Airbnb karena kemampuannya dalam menghindari aturan dan regulasi yang ditetapkan (Zervas et al., 2017). Menyangkut hal ini, Airbnb menginformasikan semua penggunanya tentang peraturan dan perundang-undangan yang berlaku di wilayah mereka beroperasi. Pengguna Airbnb diimbau untuk bekerja sama dengan otoritas dan pemilik unit setempat dalam menyampaikan regulasi yang berlaku.

Perpajakan merupakan salah satu pendekatan regulasi yang diterapkan pembuat kebijakan pada bisnis platform digital (Davidson \& Infranca, 2016). Mengingat Airbnb identik dengan biaya layanan yang lebih murah, terdapat dua skema perpajakan yang diusulkan. Yang pertama adalah memungut biaya layanan untuk tamu dan tuan rumah. Airbnb memperoleh 9-12\% dari tamu untuk setiap reservasi dan 3\% dari tuan rumah. Sebagai alternatif, pemerintah juga dapat mengenakan pajak daerah atas layanan tersebut. Sebagai contoh, pendapatan tuan rumah Airbnb di beberapa daerah di Amerika Serikat dapat dikenai pajak penghasilan. Airbnb melaporkan informasi tentang tuan rumah di Amerika Serikat yang pendapatan kotornya mencapai lebih dari USD 20.000 dan yang total transaksinya per tahun lebih dari 200 kali ke Internal Revenue Service. Airbnb hingga tahun 2020 baru memungut pajak dari tuan rumah di kota-kota tertentu di Amerika Serikat Saja. Misalnya, tuan rumah secara kolektif membayar lebih dari USD 20 juta sebagai pajak hunian di Kota New York.

Sebagai contoh lain di negara bagian Massachusetts di Amerika Serikat, Airbnb, hotel, rumah penginapan, dan motel harus membayar pajak cukai hunian kamar sebesar 5,7\% untuk setiap kamar sewaan dengan tarif lebih dari USD 15 per malam (Dalir et al., 2020). Kota-kota besar dan kecil di Massachusetts memberlakukan pajak cukai hunian kamar lokal tambahan. Singkatnya, tuan rumah Airbnb justru akan menghadapi tanggung jawab pajak yang lebih besar ketika diberlakukan pajak dengan tarif tetap. Untuk itu, sistem perpajakan yang lebih fleksibel dapat membantu pemerintah untuk mengatur dan melakukan pengawasan atas tuan rumah Airbnb. Tuan rumah juga mendapat keuntungan jika sistem perpajakan memastikan keberlanjutan pendapatan mereka.

Bali sebagai salah satu destinasi wisata utama di Indonesia, menjadi incaran berbagai pemilik unit rumah atau apartemen untuk berinvestasi. Bali, yang merupakan penyumbang lebih dari $40 \%$ wisatawan mancanegara ke Indonesia, menjadi tempat bertemunya wisatawan yang terbiasa menggunakan Airbnb sebelumnya dengan penyedia unit Airbnb. Meski demikian, bagaimana perkembangan Airbnb di destinasi wisata tersbut hingga kini belum banyak dipelajari oleh peneliti. Hal tersebut lantaran data yang dapat diakses publik terbilang mahal untuk didapatkan. Di samping itu, anggapan bahwa Airbnb telah mengganggu performa pelaku usaha perhotelan konvensional juga patut diuji kebenarannya. Sehingga kajian ini akan menggali dampak Airbnb terhadap industri perhotelan konvensional di Provinsi Bali termasuk mengidentifikasi usha pelaku industri perhotelan konvensional dalam menyikapi perkembangan Airbnb di Provinsi Bali

\section{B. METODE PENELITIAN}

Penelitian ini dilakukan dengan pendekatan deduktif, yaitu pendekatan yang menggunakan teori dan konsep yang umum dan telah dikenal sebagai alat, ukuran, atau instrument untuk membangun pertanyaan penelitian. Jenis penelitian ini adalah penelitian deskriptif dengan metode kuantitatif. Mulyadi (2013) memberikan penjelasan bahwa penelitian deskriptif (descriptive research), yang biasa disebut juga penelitian taksonomik (taxonomic research), dimaksudkan untuk eksplorasi dan klarifikasi mengenai sesuatu fenomena atau kenyataan sosial, dengan jalan mendeskripsikan sejumlah variabel yang berkenaan dengan masalah dan unit yang diteliti. 
Penelitian ini merupakan penelitian deskriptif kualitatif. Metode deskriptif adalah suatu metode dalam meneliti status sekelompok manusia, suatu objek, kondisi, sistem pemikiran ataupun peristiwa pada masa sekarang. Penelitian kualitatif adalah penelitian yang digunakan untuk mendeskripsikan dan menganalisis fenomena, termasuk sikap, kepercayaan, presepsi, dan orang secara individual maupun kelompok. Lebih lanjut, Sukmadinata (2009) menyatakan bahwa penelitian deskriptif bertujuan mendefinisikan suatu keadaan atau fenomena secara apa adanya.

Adapun lokasi penelitian ini berada pada Provinsi Bali. Penelitian ini berfokus pada unit Airbnb dan hotel konvensional di Bali. Unit Airbnb yang akan dikaji adalah tipe shared room, private room, dan entire home. Keseluruhan unit Airbnb yang dilibatkan dalam penelitian ini sebanyak 39.701 unit aktif pada saat data ini diambil pada Bulan Agustus 2020. Sedangkan untuk hotel konvensional difokuskan pada hotel bintang dan hotel non-bintang. Dalam penelitian ini, seluruh unit Airbnb di Bali dijadikan sampel penelitian. Data-data yang berkaitan dengan Airbnb, misalnya jumlah, okupansi, dan pendapatan, didapatkan melalui website Airdna. Sedangkan, data terkait dengan hotel konvensional, misalnya jumlah, tingkat penghunian kamar, dan jumlah tamu hotel diperoleh dari Badan Pusat Statistik Provinsi Bali. Namun demikian, dalam melakukan wawancara kepada pemilik maupun pengelola hotel konvensional di Bali hanya dilakukan kepada delapan hotel, yakni satu hotel bintang 5, tiga hotel bintang 4, tiga hotel bintang 3, dan satu hotel non bintang.

Data-data yang telah diperoleh pada saat pengumpulan data akan diolah dengan menggunakan metode analisis deskriptif. Untuk mengetahui dampak, Tingkat Penghunian Kamar (TPK) akan diramalkan. Tingkat hunian kamar dan pendapatan hotel berperan penting sebagai indikator kesuksesan hotel dalam menjual kamarnya. Semakin tinggi tingkat hunian berarti semakin banyak jumlah kamar yang bisa dijual dan pendapatan yang dihasilkan.

Dalam mengolah data-data penelitian, dilakukan perhitungan peramalan menggunakan metode simple seasonal dengan asumsi tidak ada perubahan kebijakan dan keadaan Indonesia stabil Data Tingkat Penghunian Kamar (TPK) yang digunakan adalah dari bulan Agustus 2017Desember 2019. Perhitungan prediksi dilakukan dari Januari 2020 hingga Desember 2025, hasil prediksi ini hanya berdasarkan dari data series Tingkat Penghunian Kamar (TPK). Tidak memperhitungan variabel-variabel lain seperti variabel pandemi, ekonomi, keamanan, politik dan kebijakan-kebijakan pemerintah.

Pengolahan data menggunakan software IBM SPSS Statistics 22. Analisis menggunakan Forecast Expert Modeler dimana model yang dihasilkan merupakan model terbaik dari SPSS dengan memperhitungkan adanya data seasonal dan berbagai model peramalan baik exponential smoothing maupun ARIMA. Asumsi yang digunakan adalah jika nilai signifikansi Ljung Box lebih besar dibandingkan nilai p-value $(0,05)$, dapat diartikan ada korelasi residual antar lag, sehingga model dapat digunakan.

\section{HASIL DAN ANALISIS}

\section{Perkembangan Usaha Perhotelan Konvensional di Provinsi Bali}

Seiring dengan meningkatnya jumlah kunjungan wisman ke Bali, secara umum terjadi peningkatan jumlah tamu asing ke hotel. Terjadi peningkatan jumlah tamu asing yang menginap di hotel bintang yang cukup tinggi pada tahun 2013 dan 2018. Sementara itu jumlah tamu asing yang menginap di hotel non bintang meski secara umum terjadi peningkatan, namun pada tahun 2015 jumlah tamu asing yang menginap di hotel non bintang sempat mengalami penurunan.

Berdasarakan Laporan BPS Bali (2020), jumlah hotel di Provinsi Bali justru mengalami penurunan. Setidaknya dapat tergambarkan pada tahun 2017-2019. Pada tahun 2017 dan 2018 jumlah hotel di Bali sebanyak 4.874 hotel (4.323 hotel non bintang dan 551 hotel bintang) dan 
mengalami penurunan pada tahun 2019 menjadi sebanyak 4.419 hotel (3.912 hotel non bintang dan 507 hotel bintang). Penurunan jumlah hotel tersebut lebih banyak terjadi pada hotel non bintang yang berkurang sebanyak 411 hotel. Penurunan jumlah hotel, baik hotel bintang maupun non bintang, mayoritas terjadi di Kabupaten Badung.

Seperti halnya dengan lama tinggal tamu, menurut BPS Bali (2020), Tingkat Penghunian Kamar (TPK) hotel bintang di Bali lebih tinggi dibandingkan dengan TPK di hotel non bintang. TPK hotel bintang pada tahun 2017-2019 sebesar 62,5\% sedangkan pada hotel non bintang hanya sebesar $32.7 \%$. Di tiap tahunnya, TPK tertinggi pada hotel bintang dan non bintang terjadi pada bulan Agustus. Hal ini terkait dengan puncak jumlah kunjungan wisatawan yang terjadi pada bulan tersebut.

\section{Gambar 1. Kunjungan wisman ke Bali dan jumlah tamu hotel bintang dan non-bintang di Provinsi Bali 2015-2018}

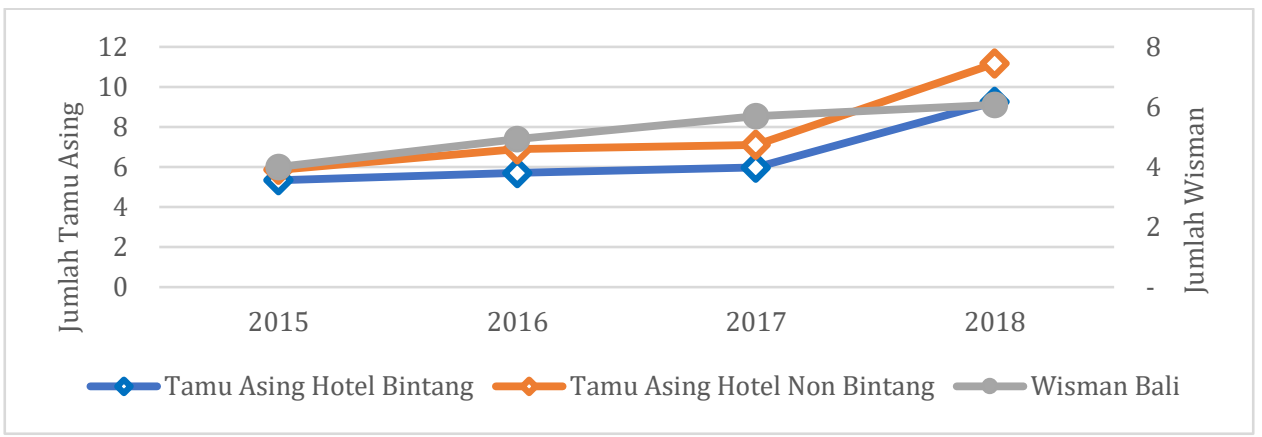

Sumber: Badan Pusat Statistik Bali, 2020

Meski terjadi penurunan jumlah hotel di Bali dan TPK yang fluktuatif, realisasi pajak dari sektor perhotelan terus mengalami peningkatan. Compound Annual Growth Rate (CAGR) penerimaan pajak secara kumulatif di Bali pada tahun 2015-2019 sebesar 10,1\%. Pada tahun 2015 realisasi penerimaan pajak hotel di Bali sebesar 1,88 Triliun rupiah dengan kontribusi terbesar terjadi pada Kabupaten Badung. Pada tahun 2019, secara kumulatif penerimaan pajak di Bali mencapai lebih dari 3 Triliun rupiah.

Dari sisi jumlah, data pendapatan masing-masing kabupaten/kota yang dikeluarkan Dinas Pendapatan dan Aset Daerah menunjukkan bahwa penerimaan pajak hotel terbesar terjadi di Kabupaten Badung. Penerimaan pajak hotel yang besar tersebut mengingat banyaknya hotel bintang di kabupaten tersebut. Penerimaan pajak hotel terendah di Bali terjadi di Kabupaten Bangli yang hanya memperoleh 293 juta pada tahun 2019. Meski demikian, dalam rentang 2015-2019 secara umum terjadi peningkatan penerimaan pajak hotel di setiap kabupaten/kota, kecuali Kabupaten Tabanan. CAGR penerimaan pajak dari sektor perhotelan terbesar terjadi di Kabupaten Jembrana yakni sebesar 39,1\%. Sedangkan pada Kabupaten Tabanan, CAGR penerimaan pajak hotelnya tumbuh negatif 8,7\%. Melihat penerimaan pajak hotel tersebut, jika diasumsikan bahwa pajak tersebut sebesar 10\% dari pendapatan hotel, maka jumlah pendapatan perhotelan di Provinsi Bali pada tahun 2015 sebesar 18,8 Triliun Rupiah dan pada tahun 2019 mencapai 30 Triliun Rupiah.

\section{Perkembangan Platform Airbnb di Bali}

Dari segi persebarannya, mayoritas unit Airbnb di Bali berada di destinasi wisata unggulan Bali, terutama di Bali bagian Selatan. Konsenterasi unit Airbnb di Bali berada di sekitar Pantai Kuta hingga Seminyak, Ubud, dan sekitar Pantai Sanur, serta sekitar daya Tarik wisata Garuda Wisnu Kencana, 
Uluwatu, dan Pantai Pandawa. Di bagian utara Bali, meski tidak sebanyak di bagian selatan, konsenterasi unit Airbnb berada di sekitar daya Tarik wisata seperti di sekitar Singaraja dan Pantai Lovina serta Pantai Amed di Karangasem.

Berdasarkan data MarketMinder Airdna.co, dibandingkan jumlah tamu pada tipe private room dan shared room, jumlah tamu yang memilih menggunakan tipe entire home jauh lebih banyak. Tren jumlah tamu pengguna tipe entire home ini seperti pola seasonality jumlah kunjungan wisman ke Bali di mana jumlah tamu yang paling banyak menggunakan tipe tersebut terjadi pada Bulan Agustus. Jika dibandingkan dengan tahun sebelumnya, jumlah tamu pada tahun 2019 cenderung mengalami peningkatan.

\section{Gambar 2. Peta Persebaran Unit Airbnb di Bali 2020}

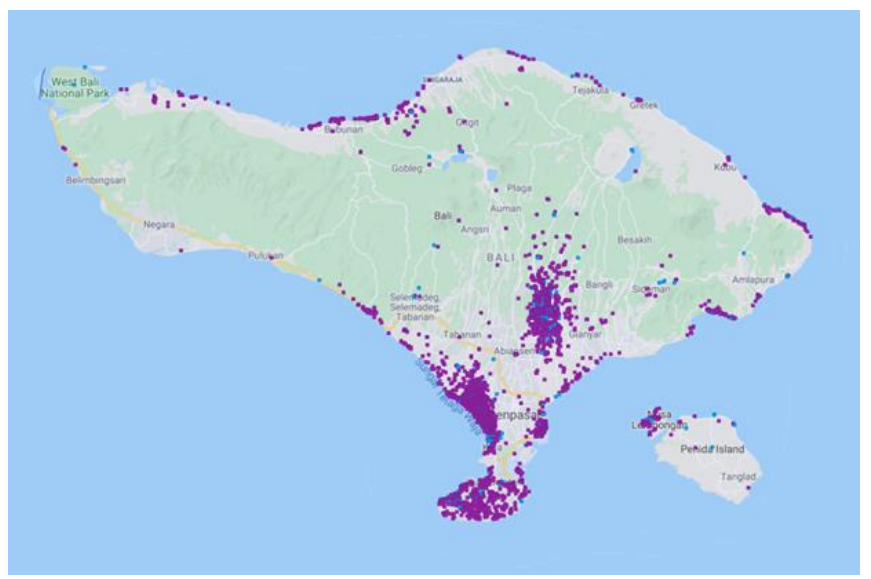

Sumber: Airdna.co, 2020

Kunjungan tamu pada tipe entire home mencapai puncak tertinggi pada bulan Agustus 2019 dengan jumlah tamu mencapai 53.846 tamu. Sementara itu, puncak tertinggi kunjungan tamu di tipe private home terjadi di bulan September 2019 dengan jumlah tamu mencapai 13.279 tamu. Sedangkan, pada tipe shared room, kunjungan tamu tertinggi justru terjadi pada Agustus 2018 yakni sebanyak 385 tamu.

Secara umum jumlah unit Airbnb yang tersedia di Bali sejak bulan Agustus 2017 sampai Desember 2019 relatif terus mengalami peningkatan secara stabil. Dilihat dari jumlahnya, tipe shared room cenderung lebih sedikit daripada tipe yang lain. Rata-rata jumlah active listing tipe shared room pada rentang waktu tersebut sebesar 510 unit saja. Sementara itu, meskipun tipe private room jumlahnya tidak sebanyak tipe entire room, juga mengalami peningkatan jumlah unit. Puncak ketersediaan unit tipe private room terjadi pada Agustus 2019 dimana unit yang tersedia sebanyak 20.314 unit. 


\section{Gambar 3. Grafik jumlah tamu yang menginap di unit Airbnb di Bali pada Agustus 2017-} Desember 2019

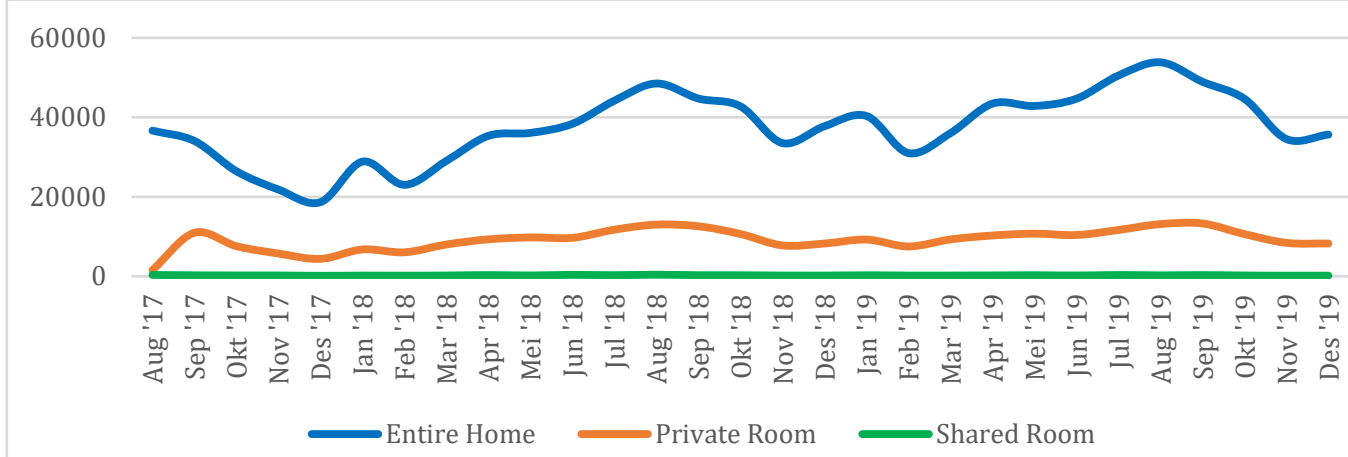

Sayangnya, setelahnya ketersediaan unit tipe private room terus mengalami penurunan sampai pada bulan November 2019, dimana hanya tersedia 13.439 unit saja. Tipe entire room merupakan tipe yang paling banyak tersedia di Bali. Sejak Agustus 2017 hingga Desember 2019, rata-rata jumlah unit dengan tipe entire room tiap bulannya mencapai 19.101 unit. Tipe tersebut juga mengalami pengingkatan seperti halnya pada tipe private room. Namun, puncak ketersediaan unit dengan tipe entire room terjadi pada bulan September 2019 dan juga mengalami penurunan pada bulan November 2019.

Harga sewa unit Airbnb dengan tipe entire room cenderung lebih mahal dibandingkan dua tipe lainnya. Harga sewa unit dengan tipe entire room berkisar antara 2-2,5 juta rupiah per hari dengan harga sewa tertinggi seringkali terjadi pada bulan Desember setidaknya pada tahun 2017 dan 2018. Sementara itu, meski dari segi ketersediaannya tidak terlampau jauh engan ketersediaan tipe entire room, harga sewa tipe private room cenderung lebih murah. Harga sewa tipe private room rata-rata berkisar antara 400-500 ribu rupiah. Sedangkan harga sewa tipe shared room relatif paling murah dengan range harga berkisar antara 150-250 ribu rupiah.

Secara umum tingkat okupansi kamar pada unit Airbnb hamper mengalami pola yang sama. Pada bulan Desember, ketiga tipe unit Airbnb cenderung mengalami penurunan okupansi, dan pada bulan Agustus mengalami puncak okupansi. Dibandingkan tipe private room dan shared room, tipe entire room memiliki occupancy rate yang paling tinggi, yang berkisar 35\% hingga 75\%. Sementara itu tipe private room memiliki occupancy rate yang berkisar antara $23 \%$ hingga $59 \%$. Sedangkan tipe shared room memiliki occupancy rate yang paling rendah, di mana okupansinya tidak pernah menyentuh $40 \%$.

Pendapatan per jumlah kamar yang tersedia (RevPAR) tertinggi pada unit Airbnb di Bali yaitu pada tipe entire home. RevPAR pada tipe entire home tertinggi terjadi setiap bulan Agustus dan cenderung mengalami penurunan pada bulan November. Puncak tertinggi RevPAR pada entire home terjadi pada bulan Agustus 2019 dengan pendapatan mencapai lebih dari 50 juta rupiah per bulan. Sementara itu tipe private room dan shared room memiliki RevPAR yang relative kecil dan memiliki pola yang hamper sama. Pada tipe private room, puncak tertinggi RevPAR juga terjadi pada bulan Agustus. RevPAR kedua tipe tersebut tidak pernah mencapai 10 juta rupiah per bulan. RevPAR tipe private room berkisar antara 2-7 juta rupiah per bulan sedangkan untuk tipe shared room berkisar pada rentang 500 ribu hingga 2,2 juta rupiah per bulan.

\section{Dampak Platform Airbnb di Provinsi Bali}

Dampak Airbnb Berdasarkan Tingkat Penghunian Kamar 
Berdasarkan hasil diatas, diperoleh hasil bahwa tingkat penghunian hotel bintang bersinggungan pertama kali pada bulan Oktober 2018. Bulan selanjutnya, tingkat penghunian kamar hotel bintang cenderung lebih rendah daripada tingkat penghunian kamar Airbnb dengan tipe Entire Home. Berdasarkan pemodelan, diprediksi tingkat penghunian kamar Airbnb dengan tipe Entire Home akan terus meningkat mengalahkan tingkat penghunian kamar hotel bintang. Sementara itu, meskipun tingkat penghunian kamar hotel bintang diprediksi akan meningkat, namun ke depan tingkat penghunian Airbnb dengan tipe Entire Home masih akan lebih tinggi.

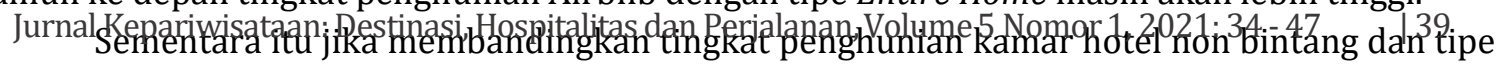
entire home, tidak nampak adanya persinggungan. Tingkat penghunian kamar tipe entire home cenderung lebih besar. Hal ini juga dapat menunjukkan adanya perbedaan segmentasi pasar antar kedua jenis penginapan tersebut.

Berdasarkan hasil pemodelan, diperoleh hasil bahwa tingkat penghunian hotel bintang bersinggungan dengan tingkat penghunian Airbnb tipe Private Room pertama kali pada bulan Januari 2019 dan kemudian mengalami 4 kali persinggungan setelahnya. Hingga Desember 2019 tingkat penghunian kamar hotel bintang cukup fluktuatif, seringkali lebih tinggi daripada tingkat penghunian Airbnb tipe Private Room. Namun ke depan, diprediksi tingkat penghunian kamar Airbnb dengan tipe Private Room akan cenderung lebih tinggi daripada tingkat penghunian kamar hotel bintang. Sementara itu, berdasarkan pemodelan, meskipun tingkat penghunian kamar hotel non bintang diprediksi akan meningkat, namun ke depan tingkat penghunian Airbnb dengan tipe Private Room masih akan lebih tinggi.

Selain itu, diperoleh hasil bahwa tingkat penghunian hotel bintang bersinggungan dengan tingkat penghunian Airbnb tipe Shared Room pertama kali pada bulan Desember 2019. Setelahnya, diprediksi tingkat penghunian kamar hotel bintang akan cenderung lebih rendah dibandingkan dengan tipe Private Room. Sementara itu, berdasarkan pemodelan, tingkat penghunian kamar non hotel pertama kali bersinggungan dengan tingkat penghunian Airbnb tipe Shared Room pada Januari 2018. Dengan menggunakan data dari bulan Agustus 2017, diperoleh hasil yang menunjukkan Tingkat Penghunian Kamar (TPK) di Provinsi Bali cenderung mengalami kenaikan baik pada hotel bintang dan non bintang maupun Airbnb jenis Entire Home, Private Room dan Shared Room. Namun, kenaikan Airbnb cenderung akan lebih signifikan dibandingkan Hotel Bintang dan Non Bintang. Hal ini juga didasarkan pada kenyataan bahwa sebelum tahun 2020, tingkat penghunian kamar di seluruh tipe Airbnb lebih tinggi dibandingkan hotel bintang dan non bintang. Oleh karenanya, berdasarkan tren dan pemodelan terhadap perkembangan Airbnb dan hotel konvensional dapat disimpulkan bahwa usaha perhotelan konvensional di Provinsi Bali baik hotel bintang dan non bintang telah terdampak oleh Airbnb pada aspek tingkat penghunian kamar pada tahun 2019.

Tabel 1. Dampak Airbnb pada Hotel Konvensional menurut Tingkat Penghunian Kamar

\begin{tabular}{ccc}
\hline Jenis Airbnb & Pengaruh bagi Hotel Bintang & Pengaruh bagi Hotel Non-Bintang \\
\hline Airbnb Entire Home & Berdampak & Berbeda segmen \\
\hline Airbnb Private Room & Berdampak & Berbeda segmen \\
\hline Airbnb Shared Room & Berdampak & Berdampak \\
\hline
\end{tabular}

Sumber: Peneliti, 2020

Dampak Airbnb Berdasarkan Pendapatan (RevPAR)

Dengan asumsi bahwa seluruh hotel bintang dan non bintang di Bali membayar pajak perhotelan sebesar 10\%, maka dapat dikatakan bahwa dalam satu tahun kalender, total 
pendapatan hotel bintang dan non bintang di Bali secara agregat mencapai 24,3 triliun rupiah pada tahun 2017 dan meningkat menjadi 30,5 triliun rupiah pada tahun 2019. Hal tersebut berarti bahwa dalam satu bulan, rata-rata pendapatan seluruh usaha perhotelan di Bali per bulan mencapai 2,0 triliun rupiah pada tahun 2017 dan meningkat menjadi 2,54 triliun rupiah pada tahun 2019.

Dengan menjumlahkan seluruh kamar yang tersedia pada tahun 2017 di hotel bintang dan non bintang, maka pendapatan per kamar tiap bulan usaha perhotelan di Bali secara agregat mencapai 16,2 juta rupiah. Sementara itu, pada tahun 2019 pendapatan per kamar tiap bulan usaha perhotelan di Bali secara agregat mencapai 22,5 juta rupiah. Hal ini juga menunjukkan bahwa pendapatan per kamar di usaha perhotelan dari tahun 2017-2019 cenderung mengalami tren peningkatan. Sayangnya, angka statistik yang didapatkan tidak dapat diolah untuk mengetahui berapa rata-rata pendapatan masing-masing hotel bintang dan hotel non bintang per bulan.

Sedangkan, pada unit Airbnb dengan tipe entire home memiliki rata-rata pendapatan per bulan yang jauh lebih tinggi dibandingkan tipe private room dan shared room. Pada tahun 2017, jumlah rata-rata pendapatan per bulan tipe entire home mencapai 27,1 juta rupiah dan terus meningkat menjadi 36,3 juta rupiah. Sementara itu, rata-rata pendapatan per bulan pada tipe private room juga mengalami peningkatan meski tidak signifikan. Sedangkan pada tipe shared room cenderung mengalami tren menurun pada periode 2017-2019 dengan rata-rata pendapatan mencapai 1,2 juta rupiah pada tahun 2019. Namun demikian, secara agregat rata-rata pendapatan pemilik unit Airbnb di Bali per bulan hanya sebesar 10,6 juta rupiah pada 2017 dan mencapai 14 juta rupiah pada tahun 2019.

Jika membandingkan rata-rata pendapatan per bulan secara agregat, pendapatan usaha perhotelan konvensional di Bali cenderung lebih tinggi pada periode 2017-2019. Temuan ini menunjukkan tidak terjadinya penurunan jumlah rata-rata pendapatan per bulan yang diterima oleh usaha perhotelan konvensional. Dapat dikatakan, keberadaan unit Airbnb di Bali secara umum tidak membawa dampak bagi pendapatan usaha perhotelan konvensional di Bali. Namun demikian, jika hanya melihat rata-rata pendapatan per bulan unit Airbnb dengan tipe entire home, maka tipe tersebut mendapatkan rata-rata pendapatan 1,7 kali lebih tinggi dibanding rata-rata pendapatan usaha perhotelan konvensional. Sayangnya, analisis komparasi ini belum dapat membandingkan rata-rata pendapatan masing-masing jenis hotel dengan masing-masing tipe Airbnb karena keterbatasan data.

\section{Dampak Airbnb Menurut Pelaku Usaha}

Narasumber yang berasal dari sejumlah hotel di Bali mengaku telah mengetahui tentang Airbnb di Bali. Menurut mereka, Airbnb hadir sebagai keniscayaan perkembangan teknologi dan perubahan consumer behaviour. Terkait dengan dampak Airbnb, mayoritas narasumber dari hotel konvensional mengaku segmentasi pasar mereka berbeda dengan Airbnb. Mereka menganggap adanya perbedaan segmen pasar dari Airbnb dan perhotelan konvensional di Bali. Bagi mereka, Airbnb cenderung menargetkan pasar mancanegara dan free-independent traveler. Pasar pengguna Airbnb di Bali pada umumnya berasal dari Eropa, yakni Perancis, Jerman, dan sebagian dari kawasan Eropa Timur seperti Slovenia dan Latvia. Berbeda dengan segmentasi pasar perhotelan pada umumnya yang lebih besar pasarnya, seperti pasar domestik, business dan leisure traveler, maupun wisatawan asing yang berkunjung bersama keluarga/grup.

Lebih lanjut, layanan yang diberikan Airbnb dan perhotelan konvensional juga dianggap berbeda. Unit Airbnb pada umumnya hanya menyediakan tempat tinggal yang tidak mengutamakan layanan personal bagi tamu dan tamu seringkali tidak menginginkan layanan. 
Mereka cenderung menginginkan privasi. Dalam hal ini, menurut Resort Manager The Sankara Ubud, menyatakan bahwa terdapat perbedaan yang mencolok antara bisnis perhotelan konvensional dengan Airbnb dimana:

"Airbnb tidak main di servis, (model bisnis) mereka lebih cenderung bermain di sistem. Mereka menyiapkan sistem yang tailor made, calon penyewa bisa berkomunikasi terlebih dahulu dengan host sebelum mereka memesan dan memastikan amenitas yang mereka butuhkan benar-benar tersedia".

Berdasarkan hasil wawancara, sejumlah pelaku usaha perhotelan konvensional di Bali mengaku tidak merasakan dampak secara langsung yang signifikan dalam performa hotel mereka akibat perkembangan Airbnb di Bali. Bagi para pelaku usaha perhotelan konvensional, keberadaan Airbnb di Bali berdampak pada ketersediaan kamar secara umum di Bali yang kian meningkat. Hal tersebut disampaikan oleh perwakilan Indonesian Hotel General Manager Association (IHGMA) yang menyampaikan:

“...Airbnb menyebabkan inventory kamar di Bali menjadi oversupply, mereka mengambil share ketersediaan kamar yang besar. Kami heran jumlah wisatawan ke Bali tiap tahun terus meningkat namun occupancy kita selalu tetap."

Di samping itu, dampak yang dirasakan akibat keberadaan Airbnb di Bali adalah makin banyak dan beragamnya pilihan jenis akomodasi yang ada di Bali. Hal ini di satu sisi baik bagi wisatawan, karena mereka dapat memilih jenis akomodasi yang sesuai dengan kebutuhan mereka. Namun di sisi lain, bagi pelaku usaha hotel konvensional keadaan tersebut menuntut mereka untuk semakin bersaing dengan lebih banyak kompetitor.

Tidak adanya dampak yang signifikan dari keberadaan Airbnb juga diutarakan sejumlah pelaku usaha. Mereka juga mengungkapkan bahwa dari sisi pemasaran, keberadaan Airbnb tidak berdampak negatif bagi perhotelan konvensional di Bali. Justru bagi beberapa pemiliki hotel, terutama hotel non-bintang, Airbnb dijadikan saluran untuk memasarkan akomodasi mereka. Namun demikian, bagi hotel yang turut memasarkan akomodasinya melalui Airbnb, tentu pendapatan mereka akan dipangkas untuk membayar komisi bagi Airbnb.

Temuan ini konsisten dengan temuan Koh dan King (2017) serta Varma et al. (2016) bahwa pelaku usaha perhotelan konvensional di Amerika Serikat dan Singapura tidak percaya bahwa Airbnb memengaruhi mereka, karena mereka justru merasa bahwa Airbnb menargetkan segmen wisatawan yang berbeda. Namun demikian, temuan dalam penelitian tersebut mengindikasikan bahwa pelaku usaha dari hotel kelas bawah dan menengah merasa Airbnb akan berpotensi untuk mengubah industri hotel konvensional secara signifikan.

Sebaliknya, bagi pelaku usaha perhotelan konvensional, keberadaan Airbnb di Bali justru bersifat melengkapi, bukan substitusi. Beberapa pelaku usaha perhotelan yang diwawancarai mengaku menyambut baik adanya Airbnb di Bali. Hal ini terutama menyangkut pengembangan digital tourism di Bali seperti yang diungkapkan pelaku usaha B Hotel Bali:

"...saya menyembut baik adanya Airbnb karena sebuah keniscayaan perkembangan teknologi. Airbnb dapat meningkatkan exposure hotel keluarga dan non bintang di Bali."

Bagi para pelaku usaha perhotelan konvensional di Bali, permasalahan yang timbul dari berkembangnya Airbnb di Bali utamanya adalah menyangkut perpajakan, perizinan, standar pelayanan, serta perlindungan konsumen. Bagi pelaku usaha perhotelan, kurang adil jika penyediaan akomodasi berbasis aplikasi seperti Airbnb tidak mendapatkan pajak seperti yang dipungut pada usaha perhotelan konvensional. Meski dari pihak Airbnb telah menyebutkan dalam websitenya bahwa pemilik unit Airbnb di Indonesia perlu membayar pajak pertambahan nilai 
(PPN) dan pajak penghasilan (Airbnb, 2020), namun pelaku usaha perhotelan konvensional meragukan pelaporan pajak tersebut.

Permasalahan selanjutnya menyangkut perizinan. Menurut pelaku usaha perhotelan konvensional, dengan tidak adanya perizinan pada penyewaan unit Airbnb menjadikan pemerintah daerah tidak memiliki kendali untuk mengelola dan mengawasi penyewaan Airbnb di Bali. Tidak adanya perizinan ini kemudian juga menyangkut dengan masalah perpajakan hingga standar pelayanan. Selain itu, dengan tidak terkendalinya penyewaan Airbnb mengakibatkan kurangnya perlindungan terhadap konsumen jika terjadi kejadian force majeur, seperti bencana alam. Kurangnya perlindungan terhadap konsumen juga disebabkan tidak adanya kantor representative resmi Airbnb di Indonesia, sehingga apabila terjadi keluhan pelanggan dan terjadi tindak kejahatan, masalah tersebut tidak segera teratasi. Sejumlah masalah tersebut jika tidak diselesaikan, perwakilan pelaku usaha perhotelan konvensional serta asosiasi perhotelan di Bali menyampaikan kekhawatiran mereka akan image penyediaan akomodasi bagi wisatawan di Bali serta citra kepariwisataan Bali pada umumnya.

\section{Persepektif Regulator/ Pemerintah}

Dari sisi regulasi saat ini, yaitu Undang-Undang No.10 tahun 2009 tentang Kepariwisataan, Peraturan Pemerintah No. 24 Tahun 2018 tentang Pelayanan Perizinan Berusaha Terintegrasi Secara Elektronik, serta Permenpar No. 10 tahun 2018 tentang Pelayanan Perizinan Berusaha Terintegrasi Secara Elektronik Sektor Pariwisata, Airbnb belum diakui sebagai bagian dari usaha pariwisata yang sah. Begitu pula berkaitan dengan Undang-Undang No. 11 tahun 2020 tentang Cipta Kerja yang kemudian diturunkan ke Peraturan Pemerintah No. 5 tahun 2021 tentang Penyelenggaraan Perizinan Berusaha Berbasis Risiko, serta Permenparekraf No.4 tahun 2021 tentang Standar Kegiatan Usaha Pada Penyelenggaraan Perizinan Berusaha Berbasis Risiko Sektor Pariwisata, Airbnb belum masuk bagian dari bidang usaha pariwisata yang diakui. Hal tersebut disebabkan Airbnb dianggap belum memiliki produk, pelayanan, hingga pengelolaan yang terstrandar. Berbeda dengan hotel konvensional yang telah memiliki standar-standar tersebut.

Dalam hal ini, perwakilan dari Kemenparekraf setuju apabila Airbnb diatur. Meskipun persaingan usaha diserahkan kepada mekanisme pasar, namun pengaturan bisnis Airbnb tersebut dimaksudkan untuk melindungi konsumen serta mencegah turunnya destination image Bali. Hal tersebut juga perlu dilakukan agar pemerintah tidak mendapat komplain dari pengguna Airbnb apabila terjadi kejadian luar biasa (force majeur). Di samping itu, pengaturan tersebut mencegah adanya 'bom waktu' akibat pembiaran layanan Airbnb di Bali.

Beberapa hal dari Airbnb yang perlu diregulasi di antaranya mengenai zonasi kawasan untuk berusaha, perpajakan, hingga standar layanan. Namun demikian, dalam meregulasi Airbnb ini terdapat sejumlah tantangan yang harus dihadapi. Salah satunya menyangkut tidak adanya kantor representasi Airbnb di Indonesia. Hal ini menyebabkan sulitnya koordinasi hingga pengawasan layanan Airbnb di Indonesia.

Lebih lanjut, menurutnya keberadaan Airbnb seringkali bersifat melengkapi perhotelan konvensional tergantung dari daerahnya. Salah satunya Bali. Menurutnya, ada pula daerah yang tidak cocok untuk Airbnb beroperasi. Hal tersebut menurutnya tergantung kondisi sosial budaya serta pasar wisatawannya. Namun demikian, pada akhirnya pemilihan dan preferensi dikembalikan pada konsumen. Konsumen memiliki kebebasan untuk memilih akomodasi yang paling nyaman menurut mereka. Airbnb terbukti menawarkan kemudahan bagi konsumen dan keunikan unit yang tidak diberikan hotel konvensional. 
Temuan dalam kajian ini menyangkut dampak Airbnb terhadap hotel konvensional di Bali diringkas sebagai berikut:

1. Airbnb akan berpengaruh pada bertambahnya jumlah inventory kamar di Bali. Hal tersebut

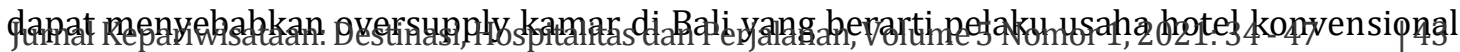
harus bersaing lebih keras untuk mendapatkan revenue dan tingkat penghunian kamar hotel yang diinginkan. Kelebihan supply tersebut menurut Dogru et al. (2019) dan Xie \& Kwok (2017) secara tidak langsung akan menurunkan RevPAR dan tingkat penghunian kamar.

2. Melalui analisis pemodelan menunjukkan bahwa secara statistik tingkat penghunian kamar hotel secara umum terdampak oleh keberadaan Airbnb. Meskipun Airbnb dengan tipe Entire Home dan Private Room diketahui memiliki segmen pasar yang berbeda dengan hotel nonbintang. Temuan ini tidak konsisten dengan temuan Dogru et al., (2019) dimana seluruh segmen hotel konvensional terdampak oleh Airbnb.

3. Berdasarkan analisis perbandingan RevPAR perhotelan yang diperoleh dari turunan realisasi pajak dengan Airbnb, ditemukan bahwa tidak ada pengaruh dari keberadaan Airbnb terhadap RevPAR hotel. Temuan ini konsisten dengan temuan Blal et al., (2018) di San Fransisco namun tidak konsisten dengan temuan Xie \& Kwok (2017).

4. Asosiasi perhotelan dan sejumlah pelaku usaha perhotelan konvensional di Bali menganggap perlunya pengaturan perizinan dan perpajakan bagi unit Airbnb untuk melindungi dan meningkatkan keamanan bagi tamu dan meningkatkan citra kepariwisataan di Bali. Dalam hal perpajakan, di Indonesia maupun di Bali secara khusus perlu dilakukan kajian yang lebih mendalam terutama menyangkut ketentuan pajak yang relevan dengan model bisnis Airbnb. Sedangkan, dalam hal perizinan, dimaksudkan untuk melegalkan bisnis yang selama ini pada umumnya dilakukan secara ilegal. Dalam hal ini, menurut Falk dan Yang (2020) melalui perizinan dan masalah pajak akan berdampak harga sewa Airbnb yang lebih tinggi dan dengan demikian meningkatkan permintaan untuk hotel.

5. Pemilik unit Airbnb dan sejumlah pelaku usaha perhotelan konvensional mengaku adanya perbedaan segmentasi pasar. Segmentasi pasar Airbnb berbeda dengan hotel konvensional sehingga Airbnb dianggap tidak berdampak bagi hotel konvensional. Hal ini sejalan dengan pendapat Guttentag (2015) yang beranggapan bahwa pasar (market) Airbnb sangat terbatas dan berbeda dengan pasar hotel konvensional.

6. Pemerintah perlu mencermati keberadaan Airbnb di wilayahnya untuk meminimalkan dampak negatif akibat layanan tersebut dan mengoptimalkan potensi kontribusi ekonomi bagi perekonomian daerah. Hal ini sesuai dengan kajian yang dilakukan Nieuwland dan van Melik (2020) dimana sebagian besar pemerintah daerah di Eropa dalam riset mereka yang justru tidak melarang Airbnb. Mereka justru ingin merangsang dampak ekonomi yang positif dari Airbnb untuk industri pariwisata, pengusaha lokal, dan tuan rumah Airbnb sambil mengurangi efek negatifnya. Dalam mengatur layanan Airbnb, pemerintah daerah juga perlu melakukan konsultasi dengan pemangku kepentingan sehingga kebijakan yang ditetapkan dapat menggabungkan dimensi inovatif dalam spektrum pariwisata (Ginindza \& Tichaawa, 2019).

\section{Usaha Menghadapi Persaingan dengan Airbnb}

Persepsi pelaku usaha perhotelan konvensional di Bali yang umumnya merasa tidak terdampak secara langsung dan signifikan terhadap keberadaan Airbnb menyebabkan tidak adanya usaha yang khusus dan spesifik dalam bersaing dengan Airbnb. Temuan di Bali ini juga konsisten dengan temuan Alrawadieh et al. (2020) di Istanbul di mana pelaku usaha perhotelan, 
terutama manager hotel budget dan kelas menengah ke bawah tidak mengimplementasikan usaha khusus akibat kekurang tahuan mereka akan Airbnb. Namun demikian, pada hotel chain yang ada di Bali memiliki usaha sendiri yang bersifat directive dari pusat. Sejumlah hotel chain seperti Hotel Westin yang tergabung dalam grup Marriott, mengusung strategi program loyalitas pelanggan, yakni Marriott Bonvoy. Usaha tersebut dianggap tepat untuk memastikan pelanggan kembali lagi. Selain itu, usaha tersebut dirancang untuk memberikan diskon besar dan fasilitas khusus untuk pengunjung yang kembali yang juga memungkinkan tamu mendapatkan poin dan mencapai level tertentu setiap tahun.

Sedangkan, pada hotel bintang lainnya, sebagian besar memutuskan bergabung dengan online travel agency (OTA) seperti Traveloka dan Booking.com. Hal tersebut dilakukan untuk meningkatkan exposure hotel mereka di internet yang dapat menjangkau pasar yang lebih luas. Selain itu, sebagian pelaku usaha perhotelan konvensional juga menyediakan website tersendiri yang memudahkan calon tamu dalam melakukan reservasi kamar. Sebagian pelaku usaha perhotelan konvensional juga membuka layanan di media sosial seperti instagram untuk lebih dekat menjangkau target pasar mereka.

Temuan di Bali tidak mengkonfirmasi sejumlah penelitian terdahulu menyangkut respon dari pelaku usaha konvensional. Beberapa bentuk respon yang dapat dilakukan oleh pelaku usaha hotel konvensional terhadap keberadaan Airbnb, yakni menawarkan ruang kamar yang lebih lega dan menurunkan harga jual (Alrawadieh et al., 2020), tidak diutarakan oleh pelaku usaha perhotelan konvensional di Bali. Selain itu, pada sejumlah kasus, misalnya di Singapura, sejumlah pelaku usaha hotel konvensional terutama hotel menengah ke bawah, menyatakan keinginannya untuk menjadikan Airbnb sebagai sarana pemasaran hotel mereka (Koh \& King, 2017). Namun demikian, narasumber dalam kajian ini tidak menyampaikan keinginan mereka untuk berkolaborasi atau bergabung dengan Airbnb.

\section{SIMPULAN}

Berdasarkan analisis dengan pemodelan, menunjukkan bahwa Airbnb telah berdampak bagi pelaku usaha perhotelan konvensional. Dampak keberadaaan Airbnb baik tipe entire home, private room, dan shared room telah berdampak bagi usaha hotel bintang di Bali. Dampak tersebut ditunjukkan pada tingkat penghunian kamar (occupancy rate) Airbnb yang bersinggungan dan akhirnya lebih tinggi dibandingkan hotel bintang konvensional. Sejak awal keberadaan Airbnb dengan tipe entire home dan private room cenderung memiliki tingkat penghunian yang jauh lebih tinggi dibanding hotel non bintang yang menunjukkan bahwa kedua tipe Airbnb tersebut memiliki segmen pasar yang berbeda. Namun, pada tipe shared room dinilai berdampak bagi usaha hotel non bintang karena tingkat penghunian kamarnya bersinggungan dan pada akhirnya memiliki tingkat penghunian kamar yang lebih baik.

Dari perspektif pelaku usaha perhotelan konvensional dan asosiasi perhotelan di Bali, keberadaan Airbnb belum dirasakan dampaknya secara secara signifikan bagi bisnis mereka. Pelaku usaha belum merasakan dampak yang signifikan terhadap pendapatan dan tingkat penghunian kamar. Menurut mereka Airbnb dan usaha hotel konvensional memiliki segmentasi/pasar yang berbeda sehingga dapat dikatakan bersifat komplementer. Sebaliknya, keberadaan Airbnb di Bali justru dianggap berdampak bagi kepariwisataan Bali secara umum. Airbnb dianggap masih belum dapat memberikan pelayanan bagi wisatawan terutama perlindungan konsumen. Selain itu keberadaan Airbnb di Bali dianggap masih menyisakan sejumlah tantangan terutama dalam hal perpajakan dan perizinan. Sejumlah faktor tersebut penting untuk memastikan citra pariwisata Bali tetap baik di mata wisatawan. 
Kajian ini menemukan bahwa perhatian pelaku usaha hotel konvensional di Bali terhadap keberadaan Airbnb utamanya menyangkut perpajakan dan perizinan. Bagi pelaku usaha hotel konvensional, Airbnb merupakan keniscayaan akan perkembangan teknologi yang canggih dan maju. Namun demikian, menurut mereka penyewaan akomodasi berbasis peer-to-peer tersebut perlu diatur dan mendapatkan perlakuan yang sama seperti usaha perhotelan. Dalam hal ini, pelaku usaha tidak

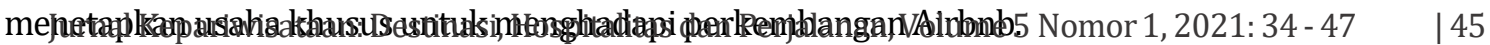

Temuan penelitian ini berimplikasi pada kebijakan pemerintah pusat dan daerah. Di tingkat daerah seperti Provinsi Bali, melihat perkembangan Airbnb yang positif, pemerintah perlu untuk mendapatkan data pemilik unit Airbnb. Hal ini sebagai dasar dalam pengelolaan dan pembinaan penyewaan akomodasi di Bali. Lebih lanjut, dengan memiliki data pemilik unit Airbnb, pemerintah daerah dapat mengelola dan mendapatkan PPN dan pajak penghasilan dari penyewaan Airbnb di Bali. Di tingkat pusat, pemerintah perlu mengkaji lebih lanjut mengenai peraturan e-commerce di Indonesia. Saat ini pemerintah pusat belum mengeluarkan kebijakan khusus untuk mengatur penyewaan rumah dan kamar melalui bisnis model peer-to-peer economy. Hal ini juga menyangkut potensi pendapatan melalui pajak penyewaan unit Airbnb yang cukup besar.

Selain itu, temuan penelitian ini juga berimplikasi manajerial terutama hotel konvensional. Pertama, ditengah dunia kepariwisataan yang terus berkembang dan semakin canggih, manajer hotel perlu terus berinovasi berbasis teknologi untuk menyesuaikan keinginan konsumen yang terus berubah. Kedua, manajer hotel konvensional perlu mengetahui kondisi inventory kamar termasuk unit Airbnb, yang ada di sekitar hotelnya untuk menetapkan strategi bersaing yang tepat. Merupakan hal yang sulit dicapai untuk mempertahankan pertumbuhan yang menguntungkan. Namun, inovasi dengan target dan ukuran yang efektif serta dikelola dengan baik dapat menghasilkan pertumbuhan yang menguntungkan.

Temuan penelitian ini hanya berfokus pada ekonomi berbagi dalam akomodasi di Bali dan hanya relevan untuk konteks Bali. Penelitian ke depan dapat dilakukan dengan mengumpulkan data-data primer dari pelaku usaha hotel konvensional dan pemilik unit Airbnb secara langsung untuk mendapatkan data yang lebih terkini. Selain itu dapat pula dilakukan analisis lainnya seperti analisis regresi untuk melihat dampak Airbnb bagi usaha perhotelan konvensional.

\section{DAFTAR REFERENSI/REFERENCES}

Benítez-Aurioles, B. (2019). Is Airbnb bad for hotels? Current Issues in Tourism, 0(0), 1-4. https://doi.org/10.1080/13683500.2019.1646226

Blal, I., Singal, M., \& Templin, J. (2018). Airbnb's effect on hotel sales growth. International Journal of Hospitality Management, 73(July 2017), 85-92. https://doi.org/10.1016/j.ijhm.2018.02.006

Chattopadhyay, M., \& Mitra, S. K. (2020). What Airbnb Host Listings Influence Peer-to-Peer Tourist Accommodation Price? Journal of Hospitality and Tourism Research, 44(4), 597-623. https://doi.org/10.1177/1096348020910211

CNN. (2017). Mengukur Bisnis AirBnB di Indonesia. https://www.cnnindonesia.com/teknologi/20171124160603-185-257867/mengukur-bisnisairbnb-di-indonesia

Dalir, S., Mahamadaminov, A., \& Olya, H. G. T. (2020). Airbnb and taxation: Developing a seasonal tax system. Tourism Economics, 27(2). https://doi.org/10.1177/1354816620904894

Davidson, N. M., \& Infranca, J. J. (2016). The sharing economy as an urban phenomenon. Yale Law and Policy Review, 215.

Dogru, T., Hanks, L., Mody, M., Suess, C., \& Sirakaya-Turk, E. (2020). The effects of Airbnb on hotel performance: Evidence from cities beyond the United States. Tourism Management, 79(January). https://doi.org/10.1016/j.tourman.2020.104090

Dogru, T., Hanks, L., Ozdemir, O., Kizildag, M., Ampountolas, A., \& Demirer, I. (2020). Does Airbnb have a homogenous impact? Examining Airbnb's effect on hotels with different organizational 
structures. International Journal of Hospitality Management, 86(January), 102451. https://doi.org/10.1016/j.ijhm.2020.102451

Dogru, T., Mody, M., \& Suess, C. (2019). Adding evidence to the debate: Quantifying Airbnb's disruptive impact on ten key hotel markets. Tourism Management, 72(June 2018), 27-38. https://doi.org/10.1016/j.tourman.2018.11.008

Falk, M. T., \& Yang, Y. (2020). Hotels benefit from stricter regulations on short-term rentals in European cities. Tourism Economics. https://doi.org/10.1177/1354816620918769

Ginindza, S., \& Tichaawa, T. M. (2019). The impact of sharing accommodation on the hotel occupancy rate in the kingdom of Swaziland. Current Issues in Tourism, 22(16), 1975-1991. https://doi.org/10.1080/13683500.2017.1408061

Koh, E., \& King, B. (2017). Accommodating the sharing revolution: a qualitative evaluation of the impact of Airbnb on Singapore's budget hotels. Tourism Recreation Research, 42(4), 409-421. https://doi.org/10.1080/02508281.2017.1314413

Lieberman, M. (2015). The Sharing Economy: Consumer Intelligence Series. https://www.pwc.fr/fr/assets/files/pdf/2015/05/pwc_etude_sharing_economy.pdf

Mulyadi, M. (2013). Penelitian Kuantitatif Dan Kualitatif Serta Pemikiran Dasar Menggabungkannya. Jurnal Studi Komunikasi Dan Media, 15(1), 128. https://doi.org/10.31445/jskm.2011.150106

Nieuwland, S., \& van Melik, R. (2020). Regulating Airbnb: how cities deal with perceived negative externalities of short-term rentals. Current Issues in Tourism, 23(7), 811-825. https://doi.org/10.1080/13683500.2018.1504899

Sukmadinata, N. S. (2009). Metode Penelitian Pendidikan. Remaja Rosdakarya.

Varma, A., Jukic, N., Pestek, A., Shultz, C. J., \& Nestorov, S. (2016). Airbnb: Exciting innovation or passing fad? Tourism Management Perspectives, 20, 228-237. https://doi.org/10.1016/j.tmp.2016.09.002

Xie, K. L., \& Kwok, L. (2017). The effects of Airbnb's price positioning on hotel performance. International Journal of Hospitality Management, 67(August), 174-184. https://doi.org/10.1016/j.ijhm.2017.08.011

Zervas, G., Proserpio, D., \& Byers, J. W. (2017). The rise of the sharing economy: Estimating the impact of airbnb on the hotel industry. Journal of Marketing Research, 54(5), 687-705.

https://doi.org/10.1509/jmr.15.0204 